\section{Range Seedings Versus Climax Vegetation on Three Sites in Idaho'}

\section{WALTER B. RUMSEY}

State Range Conservationist, Soil Conservation Service, Boise, Idaho.

\section{Highlight}

Total annual herbage yields on three range sites in Eastern Idaho in climax condition are compared with yields of introduced grasses and legumes on the same sites. Yields of introduced grasses and legumes exceeded yields of climax vegetation on all three range sites studied.

In the late nineteen fifties and early sixties, thousands of acres of dry farmland in eastern Idaho were put in the soil bank. Under this program, farmers were encouraged to take land out of wheat production and retire it to grass for a specific contract period-usually 5 to 10 years. Terms of the contract required seeding the retired land to grass or grasslegumc mixtures for soil protection and improvement. The resulting forage could not be harvested or grazed during the contract period. Seedings were established by drilling in late fall into grain stubble or summer fallow. No fertilizer was used either during establishment or in subsequent years on the plantings studied. Many excellent stands of grass on different soil series and in different rainfall zones presented an opportunity to compare relative yields over a period of years.

\section{Procedures}

Beginning in 1961, eleven seedings, four to five years old, were selected for collecting yield information. They were chosen to represent important range sites in eastern Idaho of owners whose soil bank contracts had several years to run to insure at least four years of yield data. Only fields that had full, uniform stands of the seeded species were se-

${ }^{1}$ Received November 6, 1970. lected. Differences in yield, due to variation in the stand were eliminated. The stands selected would be considered good or better for the site. Insofar as possible, fields were chosen which had uniform soils so that yields could be correlated with a specific range site.

Range managers and ranchers frequently face the decision of either managing a good stand of native species on a seedable range site or plowing the site and planting to introduced grasses and legumes. Many investigators have described the increases in forage production made possible by seeding deteriorated ranges. This study compares total annual yield of vegetation on three range sites in excellent range condition (climax vegetation) with yield of introduced grasses and legumes on the same range sites. Range sites studied were the Loamy 8 to 12 inch precipitation zone, Loamy 12 to 16 inch precipitation zonc, and Loamy 16 to 22 inch precipitation zone in eastern Idaho. The term "range site" is used here as applied by the Soil Conservation Service in making range inventories and as discussed by Dyksterhuis (1949) and Heerwagen (1959).

The studies were made on three major soil series: Lantonia, Tetonia, and Pancheri. These soils correlate with the Loamy 16 to 22 inch, Loamy 12 to 16 inch, and Loamy 8 to 12 inch range sites respectively. Table 1 provides brief descriptions of these soils.

The double plot sampling method as described by Wilm, Costello and Klipple (1944) and Frischknecht and Plummer (1949) was used to determine total herbage yield. Plants were clipped at ground level. Samples of fresh material were kept for airdry weights.

Concurrently, the Soil Conservation Service Soil-Range Interpretative Team of H. B. Passey and V. K. Hugie $(1962,1963)$ were conducting studies on native ranges in climax condition in south-central Idaho. They measured total production on 52 different study areas, seven of which were on soils which correlate into the same range sites mentioned above. These studies were made on the Roseworth, Neeley, and Pancheri soil series in the Loamy 8 to 12 inch range site and on the 
Table 1. Soil descriptions.*

\begin{tabular}{|c|c|c|c|c|c|}
\hline Name & Classification & Elev. (ft.) & Ppt. (inch) & $\begin{array}{c}\text { Effective } \\
\text { depth (inch) }\end{array}$ & Range site \\
\hline $\begin{array}{l}\text { Lantonia silt } \\
\quad \text { loam }\end{array}$ & $\begin{array}{l}\text { Pachic } \\
\text { Cryoborolls }\end{array}$ & $5800-7000$ & $15-18$ & $>40$ & $\begin{array}{l}\text { Loamy } \\
16 \text { to } 22 \text { inches }\end{array}$ \\
\hline $\begin{array}{l}\text { Tetonia silt } \\
\text { loam }\end{array}$ & $\begin{array}{l}\text { Pachic } \\
\text { Cryoborolls }\end{array}$ & $5500-7000$ & $13-15$ & $>40$ & $\begin{array}{l}\text { Loamy } \\
12 \text { to } 16 \text { inches }\end{array}$ \\
\hline $\begin{array}{l}\text { Pancheri silt } \\
\text { loam }\end{array}$ & $\begin{array}{l}\text { Xerollic } \\
\text { Calciorthids, } \\
\text { Frigid }\end{array}$ & $4200-6000$ & $8-12$ & $>40$ & $\begin{array}{l}\text { Loamy } \\
8 \text { to } 12 \text { inches }\end{array}$ \\
\hline $\begin{array}{l}\text { Roseworth silt } \\
\text { loam }\end{array}$ & $\begin{array}{l}\text { Orthidic } \\
\text { Durixerolls, } \\
\text { Frigid }\end{array}$ & $5000-5600$ & $11-13$ & $20-40$ & $\begin{array}{l}\text { Loamy } \\
8 \text { to } 12 \text { inches }\end{array}$ \\
\hline $\begin{array}{l}\text { Neeley silt } \\
\text { loam }\end{array}$ & $\begin{array}{l}\text { Calciorthidic } \\
\text { Haploxerolls } \\
\text { Mesic }\end{array}$ & $4000-5000$ & $11-13$ & $>40$ & $\begin{array}{l}\text { Loamy } \\
8 \text { to } 12 \text { inches }\end{array}$ \\
\hline $\begin{array}{l}\text { Clegg silt } \\
\text { loam }\end{array}$ & $\begin{array}{l}\text { Calcic Pachic } \\
\Lambda \text { rgixerolls, } \\
\text { Frigid }\end{array}$ & $5600-7300$ & $15-20$ & $>40$ & $\begin{array}{l}\text { Loamy } \\
12 \text { to } 16 \text { inches }\end{array}$ \\
\hline $\begin{array}{l}\text { Bancroft silt } \\
\text { loam }\end{array}$ & $\begin{array}{l}\text { Calcic } \\
\text { Argixerolls }\end{array}$ & $4500-6500$ & $13-16$ & $>40$ & $\begin{array}{l}\text { Loamy } \\
12 \text { to } 16 \text { inches }\end{array}$ \\
\hline
\end{tabular}

* Max Daniels, Soil Scientist, SCS, Boise, Idaho.

Clegg and Bancroft series in the Loamy 12 to 16 inch range site.

Although Hugie and Passey did not have study sites in eastern Idaho on the Loamy 16 to 22 inch range sites, native range yield information was available from the Teton Soil Survey Report (Soil Conserv. Serv., (1969) and the Bingham Soil Survey Report (Soil Conserv. Serv., unpublished). These sources of information were used to compare yields on rangeland in climax condition and yields from the same soils that had been seeded to introduced grasses and legumes.

In the study area, precipitation was slightly below average in 1961 and above average in 1962, 1963 and 1964 .

\section{Results}

Loamy 8 to 12 inch range site.-This site occurs on the Pancheri, Neeley, Roseworth, and similar soil series. Yields of crested wheatgrass (Agropyron cristatum) and Siberian wheatgrass (Agropyron sibericum) average 1,182 pounds air-dry herbage per acre over a four year period at three different study locations (Table 2).
Average yield of native range in excellent condition on the same range site for the same four years on four study sites was 808 pounds per acre (Table 3 ). Figure 1 illustrates variability by years. When seeded to introduced grasses, the Loamy 8 to 12 inch range site averaged about 375 pounds more per acre per year than the same site in climax condition. Composition of the climax vegetation on this sitc is approximatcly as follows:

Grasses

$30 \%-50 \%$ Dominated by bluebunch wheatgrass (Agropyron spicatum), Thurber needlegrass (Stipa thurberiana), and bluegrasses (Poa secunda).

Forbs

10\%-35\% Dominated by balsamroot (Balsamorhiza sagittata), Phlox sp., and tapertip hawksbeard (Crepis acuminata).

Shrubs

10\%-35\% Dominated by big sagebrush (Artemisia tridentata) and three-tip sagebrush (A. tripartita).

Table 2. Yields (lbs./acre, air dry) of seeded ranges.

\begin{tabular}{|c|c|c|c|c|c|c|}
\hline \multirow[b]{2}{*}{ Range site } & \multirow[b]{2}{*}{ Soil series } & \multicolumn{5}{|c|}{ Yields } \\
\hline & & 1961 & 1962 & 1963 & 1964 & Average \\
\hline Loamy, 8 to 12 inch $^{1}$ & Pancheri & 724 & 1046 & 1634 & 1320 & 1182 \\
\hline Loamy, 12 to 16 inch $^{2}$ & Tetonia & 1905 & 2749 & 3848 & 3251 & 2782 \\
\hline Loamy, 16 to 22 inch $^{2}$ & Lantonia & 2884 & 4286 & 4945 & 5680 & 4272 \\
\hline
\end{tabular}


Table 3. Total herbage yields (lbs./acre, air dry) on three range sites in climax condition in Idaho. ${ }^{1}$

\begin{tabular}{|c|c|c|c|c|c|}
\hline \multirow[b]{2}{*}{ Range site \& soil series } & \multicolumn{5}{|c|}{ Year } \\
\hline & 1961 & 1962 & 1963 & 1964 & Average \\
\hline \multicolumn{6}{|l|}{ Loamy 8 to 12 inch } \\
\hline Roseworth silt loam & 583 & 724 & 1089 & 943 & 835 \\
\hline Neeley silt loam & 589 & 849 & 957 & 756 & 788 \\
\hline Neeley silt loam & 614 & 1339 & 1173 & 757 & 971 \\
\hline Panchcri silt loam & 639 & 738 & 618 & 559 & 638 \\
\hline Average & 606 & 912 & 959 & 754 & 808 \\
\hline \multicolumn{6}{|l|}{ Loamy 12 to 16 inch } \\
\hline Clegg silt loam & 1138 & 1307 & 1320 & 1138 & 1226 \\
\hline Bancroft silt loam & 1312 & 1458 & 1042 & 1192 & 1251 \\
\hline Average & 1225 & 1382 & 1181 & 1165 & 1238 \\
\hline \multicolumn{6}{|l|}{ Loamy 16 to 22 inch } \\
\hline Lantonia-like & 一 & - & - & - & 2200 \\
\hline
\end{tabular}

Loamy 12 to 16 inch range site.-This site occurs on Tetonia, Clegg, Bancroft, and similar soil series. Seedings were measured on the Tetonia series and were mixtures of intermediate wheatgrass (Agropyron intermedium) and alfalfa (Medicago sativa) or Manchar smooth brome (Bromus inermis) and alfalfa. One seeding was smooth brome grass alone. Avcrage yiclds for the four study years, 1961 through 1964, were 2,782 pounds per acre per year (Table 2).

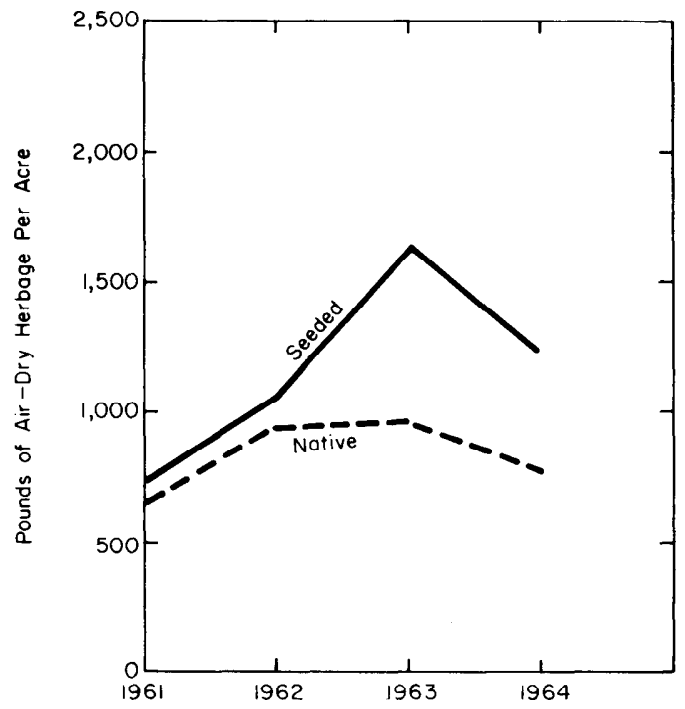

Fig. 1. Comparison of annual yields between seeded range and climax condition range. Loamy 8 to 12 inch range site. Pancherilike soils.
The same range site in climax condition averaged 1,238 pounds per acre per year on two soil serics (Clegg and Bancroft) for thc four-year period (Table 3). Seedings with alfalfa in the mixture produced over twice as much as the native range. With smooth brome alone, the site out-yielded native range by over 500 pounds per acre. Figure 2 illustrates variability by years. Composition of the climax vegetation on this site is approximately as follows:

Grasses

$65 \%-80 \%$ Dominated by bluebunch wheatgrass, Idaho fescue (Festuca idahoensis), and bluegrasses.

Forbs

15\%-20\% Dominated by tapertip hawksbeard, balsamroot, and Phlox sp.

Shrubs

10\%-20\% Dominated by big sagebrush and threetip sagebrush.

Loamy 16 to 22 inch range site.-This site occurs on the Lantonia, Karlan, Robin, and similar soil series. Seedings were measured on the Lantonia soil series and consisted of intermediate wheatgrass, Manchar smooth brome and one crested wheatgrass seeding, all with alfalfa. Average yield for four years on four study sites was 4,272 pounds per acre (Table 2). No figures are available by individual years for the native range. However, average yields on these soils of native species is approximately 2,200 pounds (Teton Soil Survey Report, 1969; Bingham

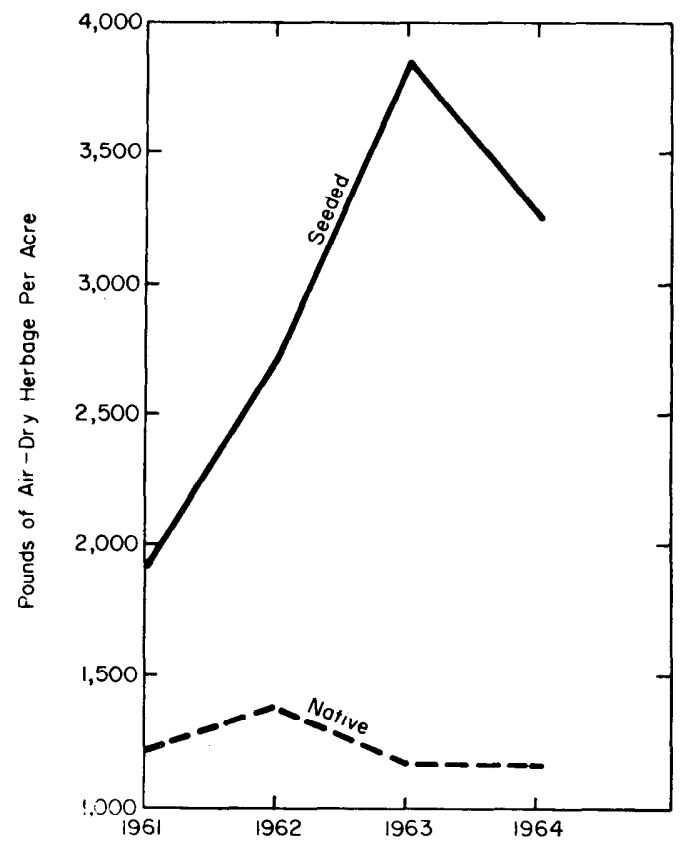

Fig. 2. Comparison of annual yields between seeded range and climax condition range. Loamy 12 to 16 inch range site. Tetonia-like soils. 


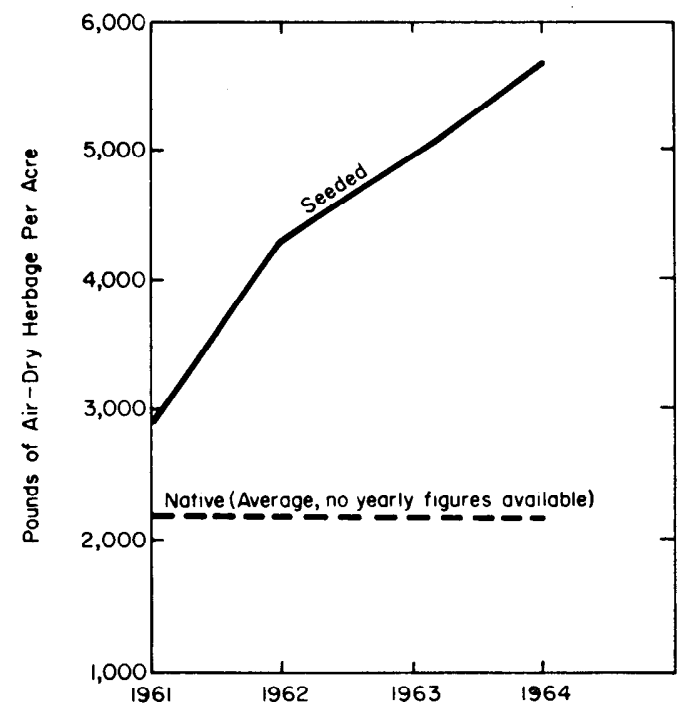

FIG. 3. Comparison of annual yields between seeded range and climax condition range. Loamy 16 to 22 inch range site. Lantonia-like soils.

County Soil Survey Report, unpublished). Seeded sites average about twice the production of the native range (Fig. 3). Composition of the climax vegetation on the site is approximately as follows:

Grasses

$55 \%-75 \%$ Dominated by Idaho fescue, bluegrasses, bluebunch wheatgrass, bearded wheatgrass (A. subsecundum), and prairie junegrass (Koleria cristata).

Forbs

10\%-25\% Dominated by geranium (Geranium fremonti), lupine (Lupinus sp.), balsamroot, and western yarrow (Achillea lanulosa).

Shrubs

5\%-10\% Dominated by bitterbrush (Purshia tridentata), snowberry (Symphoricarpos sp.), and serviceberry (Amelanchier alnifolia).

\section{Discussion}

This study indicates that three range sites in eastern Idaho will produce significantly more herbage when seeded to introduced grasses and legumes than they will in climax condition.
The increased production of seeded ranges over the native range for a four-year period average $146 \%$ for the Loamy 8 to 12 inch site, $224 \%$ for the Loamy 12 to 16 inch site, and $194 \%$ for the Loamy 16 to 22 inch site.

Since native ranges grow significant percentages of plants that are only lightly used by some classes of grazing animals, the spread between stocking rates would be even higher. Many investigators have demonstrated the dramatic increases when poor condition ranges are seeded. This study indicates that good seedings will produce significantly more than the best native ranges on the sites and soils studied. However, it may seldom be desirable to convert seedable, climax condition ranges to introduced grasses and legumes. Several factors must be considered. In some cases, the variety of forage offered by the native range is more valuable to both wildlife and livestock than the single or dual species seeding. In addition, such things as kind and class of livestock, seasonal forage balance, possible effects on the range ecosystem, wildlife, and cost-benefits must be carefully evaluated. Therefore, even though a given site might be capable of producing more pounds of forage from introduced species, other factors often weigh in favor of leaving it in native vegetation.

\section{Literature Cited}

Dyksterhuis, E. J. 1949. Condition and management of rangeland based on quantitative ecology. J. Range Manage. 2:104-115.

Frischknecitt, Neil C., ANd A. Perry Plummer. 1949. A simplified technique for determining herbage production on range and pasture land. Agron. J. 41:63-65.

HeERWAGen, ARnold. 1958. Management as related to range sites in the central plains of eastern Colorado. J. Range Manage. 11:5-9.

Passey, H. B., AND V. K. Hugie. 1962. Application of soil-climate-vegetation relations to soil survcy interpretations for rangeland. J. Range Manage. 15:162-166.

Passey, H. B., AND V. K. Hugie. 1963. Fluctuating herbage production on an ungrazed Sierozen soil in Idaho. $\mathrm{J}$. Soil and Water Conserv. 18(1):8-11.

Soll Conservation Service. 1969. Teton County soil survey report. Soil Conserv. Serv. Boise, Idaho. p. 58-62.

Soil Conservation Service. (unpublished). Bingham County soil survey report. Soil Conserv. Serv. Boise, Idaho. p. 70-73.

Wilm, H. G., D. C. Costello, and G. F. Klipple. 1944. Estimating forage yicld by the double sampling method. Amer. Soc. Agron. J. 36:194-203.

\section{Specialists in Quality NATIVE GRASSES}

Wheatgrasses • Bluestems • Gramas • Switchgrasses • Lovegrasses • Buffalo • and Many Others

We grow, harvest, process these seeds

Your Inquiries Appreciated Native Grasses Harvested in ten States 